\title{
BEHAVIORAL AND ENVIRONMENTAL DETERMINANTS OF LEPTOSPIROSIS: A NEW EVIDENCE FROM KLATEN, CENTRAL JAVA USING A PATH ANALYSIS MODEL
}

\author{
Maya Sofiyani'), Ruben Dharmawan 2), Bhisma Murti1) \\ 1) Masters Program in Public Health, Universitas Sebelas Maret \\ 2)Faculty of Medicine, Universitas Sebelas Maret
}

\begin{abstract}
Background: Leptospirosis is a bacterial disease that affects both humans and animals. Humans become infected through direct contact with the urine of infected animals or with a urine-contaminated environment. The bacteria enter the body through cuts or abrasions on the skin, or through the mucous membranes of the mouth, nose and eyes. Person-to-person transmission is rare. Leptospirosis a global public health issue, with an estimated annual incidence of 0.1 to 1 case/100,000 population in moderate non-endemic area, and 10 to 100 cases/100,000 population in humid and tropical endemic areas. Indonesia is the third country in the world with the highest Leptospirosis-attributable mortality. Its fatality rate ranged from $2.5 \%$ to $16.45 \%$ with an average of $7.1 \%$. This study aimed to analyze the risk factors of Leptospirosis in Klaten, Central Java.

Subjects and Method: This was a case control study conducted in Klaten, Central Java, from October to November, 2017. A sample of 49 Leptospirosis cases and 101 non-diseased controls were selected for this study by fixed disease sampling. The independent variable were employment status, history of cuts, history of water excursion, use of personal protective equipment (PPE), house condition, environmental condition, presence of mouse or cattle, history of rain or flood. The dependent variable was Leptospirosis. The data were collected by questionnaire and analyzed by path analysis.

Results: The determinants that increased the risk of Leptospirosis were history of cuts ( $\mathrm{b}=1.64 ; 95 \% \mathrm{CI}=0.40$ to $2.87 ; \mathrm{p}=0.009)$, history of water excursion $(\mathrm{b}=$ $1.98 ; 95 \% \mathrm{CI}=0.52$ to $3.43 ; \mathrm{p}=0.008)$, poor house condition $(\mathrm{b}=-1.92 ; 95 \% \mathrm{CI}=$ -3.08 to $-0.77 ; \mathrm{p}=0.001)$, and poor environmental condition $(\mathrm{b}=-2.35 ; 95 \% \mathrm{CI}=-$ 3.48 to $-1.23 ; \mathrm{p}<0.001)$. History of cuts increased with cattle-related work $(\mathrm{b}=$ 1.79; $95 \% \mathrm{CI}=0.86$ to $2.72 ; \mathrm{p}<0.001)$ and absence of $\mathrm{PPE}(\mathrm{b}=-2.54 ; 95 \% \mathrm{CI}=-$ 3.49 to $-1.60 ; \mathrm{p}<0.001)$.

Conclusion: The behavioral and environmental determinants that increase the risk of Leptospirosis are history of cuts, history of water excursion, poor house condition, and poor environmental condition.
\end{abstract}

Keywords: determinants, behavioral, environmental, leptospirosis

\section{Correspondence:}

Maya Sofiyani. Masters Program in Public Health, Universitas Sebelas Maret, Jl. Ir. Sutami 36 A, Surakarta, 57126, Central Java, Indonesia.

Email: mayasofiani@rocketmail.com. 